\title{
Factors impeding African immigrant entrepreneurs' progression in selected small and medium enterprises: Evidence from a local municipality in South Africa
}

\begin{tabular}{|c|c|}
\hline \multicolumn{2}{|c|}{$\begin{array}{l}\text { Authors: } \\
\text { Bernard L. Ngota }{ }^{1} \text { (]) } \\
\text { Eric E. Mang'unyi }{ }^{1} \text { (]) } \\
\text { Sookdhev Rajkaran }{ }^{1} \text { (1) }\end{array}$} \\
\hline \multicolumn{2}{|c|}{$\begin{array}{l}\text { Affiliations: } \\
{ }^{1} \text { Faculty of Commerce and } \\
\text { Administration, Walter Sisulu } \\
\text { University, South Africa }\end{array}$} \\
\hline \multicolumn{2}{|c|}{$\begin{array}{l}\text { Corresponding author: } \\
\text { Eric Mang'unyi, } \\
\text { mangunyie@gmail.com }\end{array}$} \\
\hline \multicolumn{2}{|c|}{$\begin{array}{l}\text { Dates: } \\
\text { Received: } 29 \text { Aug. } 2016 \\
\text { Accepted: } 26 \text { Aug. } 2017 \\
\text { Published: } 26 \text { July } 2018\end{array}$} \\
\hline \multicolumn{2}{|c|}{$\begin{array}{l}\text { How to cite this article: } \\
\text { Ngota, B.L., Mang'unyi, E.E. \& } \\
\text { Rajkaran, S., 2018, 'Factors } \\
\text { impeding African immigrant } \\
\text { entrepreneurs' progression in } \\
\text { selected small and medium } \\
\text { enterprises: Evidence from a } \\
\text { local municipality in South } \\
\text { Africa', South African Journal } \\
\text { of Business Management } \\
49(1) \text {, a10. https://doi.org/ } \\
\text { 10.4102/sajbm.v49i1.10 }\end{array}$} \\
\hline \multicolumn{2}{|c|}{$\begin{array}{l}\text { Copyright: } \\
\text { ๔ 2018. The Authors. } \\
\text { Licensee: AOSIS. This wo } \\
\text { is licensed under the } \\
\text { Creative Commons } \\
\text { Attribution License. }\end{array}$} \\
\hline \multicolumn{2}{|l|}{ Read online } \\
\hline 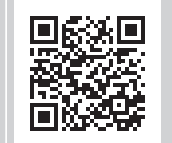 & $\begin{array}{l}\text { Scan this QR } \\
\text { code with your } \\
\text { smart phone or } \\
\text { mobile device } \\
\text { to read online. }\end{array}$ \\
\hline
\end{tabular}

\section{Authors:}

Eric E. Mang'unyi ${ }^{1}$

Sookdhev Rajkaran ${ }^{1}$

Affiliations:

University, South Africa

Corresponding author:

Eric Mang'unyi,

Dates:

Accepted: 26 Aug. 2017

How to cite this article:

Ngota, B.L., Mang'unyi, E.E. \&

Rajkaran, S., 2018, 'Factors impeding African immigrant entrepreneurs' progression in enterprises: Evidence from a local municipality in South Africa', South African Journa 49(1), a10. https://doi.org/

\section{Copyright:}

(c) 2018. The Authors. is licensed under the Creative Commons Attribution License.

mobile device
This study examines factors inhibiting African immigrant entrepreneurs' small and medium enterprises' (SMEs) growth in a municipality of South Africa. Understanding these factors is important to stakeholders as this is an area that plagues much of the immigrant entrepreneurship literature. The study is descriptive in nature, and data were sourced from active African immigrant entrepreneurs through a quantitative approach. Random sampling was used to identify a total of 75 businesses. The results indicated that access to credit from regulated financial institutions is a mirage and that Afrophobic attacks on businesses dwindles prospects of entrepreneurship, job and wealth creation, thus impacting on economic growth of the region. To help bring 'long-lasting' co-existence between immigrant entrepreneurs and natives, formulation and implementation of 'liberal' integrated public policy interventions and strategies are needed. This would help in having a positive impact on the region's prosperity in terms of job creation, poverty reduction and economic growth, in turn improving the peoples' well-being. Given the migratory patterns and greater human global mobility, debate on integrated approaches among or within government systems should never be obscure as it is one of the biggest challenges in the continent.

\section{Introduction}

The 21st century has witnessed many countries around the world experience increased migration caused by political instability, economic reasons and globalisation, among others (Crush \& Ramachandran 2009; Fatoki \& Patswawairi 2012; Khosa \& Kalitanyi 2015; United Nations 2006). According to McKinley (2006), immigration is essential, unavoidable and a potentially beneficial component of the economic and social life of countries and regions. Since its independence in 1994, South Africa has recorded an increase in immigrants ${ }^{1}$ from all parts of the world, and specifically from other African countries (Crush \& Ramachandran 2009). South Africa is regarded as a country with abundant business opportunities (Maharaj 2004 cited in Mudi-Okorodudu 2011:11), pleasingly deep traditions and renowned tourist allures (Asoba \& Tengeh 2016:97), as well as long-standing patterns of labour migration, peace and prosperity (Landau, Ramjathan-Keogh \& Singh 2005) making these among the driving forces of migration into the country. Despite the 'potential' benefits of immigration, it remains a challenge to the South African government particularly in respect to the socio-economic integration of migrants. While the task of formulation and implementation of strategies to handle competing interests of immigrants and local communities in entrepreneurship seem to be getting more difficult, such aforementioned scenario calls for inter alia local and national policy shifts.

It is difficult for immigrants to enter into the labour market (Bogan \& Darity 2008; Khosa \& Kalitanyi 2015); therefore, entrepreneurship becomes a better option. A study by Khosa and Kalitanyi (2015) revealed that ambition led to immigrant entrepreneurship for the sole reason of earning a living and confront discrimination in the labour market. With an estimated $24.3 \%$ rate of unemployment (Statistics South Africa 2014), immigrants may be of great significance to the economy in the creation of new businesses and hence contribute to the reduction of the endemic South Africa's high joblessness rate. There have been calls for the recognition of the contribution of immigrants to the extraordinary prosperity of a country (Shary 2000). Washinyira (2015)

1.In this study, the terms 'immigrant' and 'migrant' have been used interchangeably and imply the same meaning. 
asserts that through their businesses, migrants serve the needs of poorer consumers by making goods and services at inexpensive prices.

There has been considerable interest on research on immigrants' significant social and economic roles (Lemes, Almeida \& Hormiga 2010). Some authors (Liedeman et al. 2013) have pointed out that since 2005, there has been aggressive competition between native-owned small business operators and businesses ran by African immigrants. The aforementioned researchers further sought to understand the nature and the impact of apparent dominance of alien businesses over their South African counterparts. They concluded that immigrantowned businesses were flourishing in almost all local communities within the Republic of South Africa (Liedeman et al. 2013). Washinyira (2015) contends that immigrants usually work long hours and portray a culture of prudence and thus prosper. Bear et al. (2005) asserted that a decline of South Africans' operating businesses was inevitable as a result of their unattractiveness. However, the nature of this uncompetitiveness is still contestable. The dynamism of how immigrant entrepreneurs succeed in their business operations still raises a lot of controversy within the South African Small and Medium Enterprises' (SMEs) ${ }^{2}$ sphere (Liedeman et al. 2013). As such, there have been interest and calls from some government quarters on foreigners to share ideas of successful entrepreneurship with South Africans SMEs owners' (Fatoki 2010; Timeslive 2015:1). Furthermore, the government developed an institutional model to support immigrant small business (Tengeh 2013). This was intended to reduce resentment and create an impression that the South Africa's business spaces are not being taken away by immigrants.

African immigrant entrepreneurs in many cities in South Africa are confronted with numerous challenges that have severe impact on their entrepreneurial endeavours. Some of these challenges are detrimental to their enterprises, often leading to closure. The main challenge that has been a concern to African immigrant entrepreneurs' is afrophobia (Crush 2000; Human Rights Commission 1999; Matsinhe 2011), which some scholars (e.g. Canetti-Nisim \& Pedahzur 2003; Crush \& Ramachandran 2009; Thulani 2015) refer to as hostility or aversion meted on people, culture or ideas of African derivation particularly those of sub-Saharan negroid origin. Although unsubstantiated, Kalitanyi and Visser (2010) assert that South Africans have always held a belief that immigrants from northern countries bordering South Africa are taking up their jobs. Crush, Ramachandran and Pendleton (2013) and Clive (2015) have both posited that afrophobia and coordinated acts of violence have been exacerbated with the implicit endorsement of the communities and leaders in which immigrant businesses operate. In addition, Gastrow and Amit (2012) assert that there is failure by the justice and legal systems to abate ferocity by leaving such crimes unpunished, thus leading to increased criminal activities against foreigners and their businesses. The rapid 2.Small and medium enterprises in this study context also include micro businesses. and extensive transition in migrant small business ownership has been recognised in research (Asoba \& Tengeh 2016; Khosa \& Kalitanyi 2015; Radipere 2012). Since 2008 there has been a growing interest in enquiries that seek to understand the nature of afrophobic violence directed at immigrants and the impact on their SMEs. Relatively limited published research on this topic (in the municipality under investigation) has been conducted with specific reference to the challenges faced by small businesses owned by African immigrants. Some authors like Fatoki (2014) and Tengeh, Ballard and Slabbert (2012) have called for more quantitative exploration in this area. The purpose of this article was to identify and understand the central issues as perceived by African immigrant SMEs business owners' impacting on their business growth intentions in South Africa. By bringing to the fore the challenges immigrant entrepreneurs' face in their normal business operations, the governments (local, provincial and national) would understand the issues to enable the formulation of policy long-term support. The following research question guided the study, from which this article was extracted: What are the challenges confronting advancement of SMEs owned by African immigrant entrepreneurs in Mthatha locale, O.R. Tambo District Municipality?

Consequently, the following related research sub-questions were posited:

RQ1: What are the challenges confronting the growth of African immigrant-owned businesses in the local municipality of Mthatha?

RQ2: What impact does the identified issues in (RQ1) above have on job creation and economic well-being in the local municipality of Mthatha?

RQ3: What strategies must be put in place to improve, sustain and encourage growth of immigrant-owned SMEs in O.R. Tambo District Municipality?

\section{Literature review}

\section{Immigrant entrepreneur and entrepreneurship in context}

For quite some time, there has been an increased interest in studies on immigration and entrepreneurship and the effect on socio-economic integration of immigrants (Dana 2007). The concept of entrepreneurship entails creating value through recognition of a business opportunity while managing risk associated to it and being able to apply communication and management skills that would help mobilise human, financial and material resources necessary for the realisation of the idea (Veerabhadrappa 2009). According to some researchers (e.g. Aaltonen \& Akola 2014; Vinogradov 2008), an immigrant entrepreneur is an individual who has moved to a different country and established a business. Kahn et al. (2013) assert that many immigrant entrepreneurs possess foreign nationalities and thus lack host country's citizenship status. Aaltonen and 
Akola (2014) further state that an immigrant entrepreneur or business proprietor holds a foreign status and is involved in entrepreneurship activities of economic innovation and business improvement while seeking profit in a given market sub-sector. Dalhammar (2004) concludes that immigrant entrepreneurship therefore is the process by which someone establishes a business in a host country other than his or her native country. In summary, the two concepts briefly discussed above highlight the nexus between them, making it relevant to this study in the O.R. Tambo District.

\section{Immigrant entrepreneurship and small and medium enterprise distribution in South Africa}

Fatoki (2010) asserts that there has been fast development of immigrant-owned businesses in South Africa, and accordingly, the government has developed a support framework (Tengeh 2013). However, the political, social and economic transitions witnessed in recent years have influenced the government to issue business permits albeit to a handful entrepreneurs and particularly those from Eastern Europe and Asia (Benedict \& Venter 2010). It is factual that there exists a high unemployment rate in South Africa (OECD 2013; Statistics South Africa 2014), as well as discriminatory tendencies in the labour market, thus pushing many immigrants into entrepreneurship (Kalitanyi \& Visser 2010). An earlier study by Hiebert (2002) showed that immigrants were more prone to self-employment than the native-born population. According to Statistics South Africa (Stats SA 2010), immigrant SMEs account for 2.5\% of the total SMEs' population, out of which $2 \%$ are new and are not evenly distributed (Stats SA 2009) as reflected in Table 1. Eastern Cape Province is the fourth in the list of South Africa's provinces with the highest numbers of both formal and informal immigrant SMEs. Nestorowicz (2011) argues that as a result of the dynamics of the business market, migrants need to consider various factors before establishing their businesses, which include culture, friendliness, business sustenance systems, competitiveness and ease of access to the market.

\section{Contribution of immigrant entrepreneurship to the South African small and medium enterprise economy}

Studies on migrant entrepreneurial activities have shown improvements in the overall country's economic growth. A study by Fairlie (2012) to determine the apparent significant contribution of immigrant business owners to the U.S. economy revealed that $12 \%$ of the total business income

\begin{tabular}{llcc}
\multicolumn{4}{l}{ TABLE 1: Distribution of immigrant small and medium enterprises. } \\
\hline$\#$ & Province & Informal sector & Formal sector \\
\hline 1. & Gauteng & 48.3 & 24.6 \\
2. & Western Cape & 19.0 & 5.9 \\
3. & KwaZulu-Natal & 13.0 & 18.8 \\
4. & Eastern Cape & 5.3 & 13.4 \\
5. & Mpumalanga & 4.1 & 7.7 \\
6. & Free state & 3.2 & 6.6 \\
7. & North-West & 3.2 & 8.0 \\
8. & Limpopo & 2.9 & 14.3 \\
\hline
\end{tabular}

Source: Statistics South Africa Business Register 2009 was generated by immigrant business owners. In addition, it was ascertained that immigrant entrepreneurs establish $17 \%$ of all new start-ups in the United States, a representation of about $13 \%$ of all business owners (Fairlie 2012). It can be deduced from the abovementioned study findings that new wealth, jobs and skills are created through immigrant entrepreneurship (Kalitanyi \& Visser 2010; Radipere 2012). Hohn (2012) further stresses that it has been ascertained in recent surveys that immigrant entrepreneurs have created or co-own $25.3 \%$ of all science and technological firms in the United States. In the European Union (EU), it has been established that two thirds of jobs and related economic benefits within the EU communities are as a result of SMEs.

Typical with immigrants' model of entry and operation is that they move into low-rent neighbourhoods characterised by negligible economic activity where they establish businesses in the retail or personnel services as an alternative to securing low-wage jobs in 3-10 years of entry (Hohn 2012). Given that in any known economy, business start-ups and their growth could decrease the increasing cases of unemployment and poverty, there is dire need for new businesses in today's South Africa (Tengeh et al. 2012). In the face of overstretched and unevenly distributed financial resources of South Africa, it is becoming almost impossible for SMEs and particularly those owned by immigrants to secure financial credit lines (Khosa \& Kalitanyi 2015; Urban \& Naidoo 2012). This serves as an impediment to such businesses, thus negatively impacting on the country's economy. However, with the increased scarcity of jobs amid increasing trends of migration into South Africa over the years, small business opportunities are becoming the only attractive option in the country. A number of these businesses have succeeded in employing local workers and as Hohn (2012) asserts, they aid in economic growth because the lowincome population benefit directly through employment (Tengeh et al. 2012). Furthermore, they are gradually becoming the leading employers in South Africa's economy (Kongolo 2010).

African immigrant entrepreneurs have also contributed in bringing about new ideas and business opportunities (Schuler, Islam \& Rottach 2011) and skills such as manufacturing in the conduct of their business (Washinyira 2015). With lack of training in SME-related sector (Smith \& Watkins 2012), the majority of African immigrant workers get their training on job, that is, within the small businesses, thus raising the entrepreneurship bar needed for the development of the private sector economy (Chodokufa 2009). Because the main sources of finance and credit are personal savings in the beginning of their start-ups while they also access loans from informal money lenders (Tambunan 2009), with the advancement of their businesses, there is more saving behaviour inculcated. By this model, the little savings motivate others to follow suit other than rely on accessing a bank facility, which is virtually impossible. As well, according to Mac and Bhaird (2010), small businesses owned by 
immigrants tend to be competitive by adopting niche strategies such as flexibility, quality products and responding to the specific needs of customers. Ntsika Enterprise Promotion Agency (2012) states that with such competitive ways, immigrant entrepreneurs in South Africa tend to drive away monopoly in the local markets through specialised service and product provision. This is because such businesses bring in new ideas as well as improve product and service offerings. According to Radipere and Dhiwayo (2013), the sustained fierce competition from African immigrant entrepreneurs has pushed larger firms into serious market research and advertisements. Continued competition has inevitably steered improved environment of doing business as well as enhanced quality of products and services (Mason \& Rown 2013).

\section{Challenges confronting African immigrant businesses in South Africa}

Clearly, a plethora of research studies (Asoba \& Tengeh 2016; Crush et al. 2013; Khosa \& Kalitanyi 2015) allude to the fact that African immigrant entrepreneurs encounter numerous obstacles at the beginning and growth phases of their businesses (Tengeh \& Lapah 2013). Unique to South Africa is afrophobia, which seems to have adverse consequences on job creation and trading activities (Hunter \& Skinner 2003). Crush (2000) states that South Africa has increasingly become afrophobic in recent years with large percentage of citizens perceiving black foreigners as 'dangerous' and 'undesirable'. Since 2008, this phenomenon is widespread in the townships where immigrants have inhabited. Immigrants are therefore more often stereotyped as a threat to the economic and social interests of South Africans. Cronje (2009) classifies causes of afrophobia into three broad areas, namely (1) corruption perceived to exist in almost all government systems, (2) high levels of unemployment rate standing at over $20 \%$ with the youth aged between 15 and 34 years being the majority at $70.9 \%$ (Statistics South Africa 2014), and (3) subversion to the rule of law. De Jager (2013) further asserts that fear which builds to jealousy towards foreigners' business success leads to afrophobia .

Access to credit from sanctioned financial institutions remains a serious obstacle (Goldstuck 2015; Tengeh et al. 2012). As Fatoki (2013a) correctly puts it, access to formal debt and equity markets is restricted to immigrant entrepreneurs, occasioned by lack of credit history and collateral security among other issues. According to Cant (2012), Khosa (2014) and Mohsam and Van Brakel (2011), access to a reasonable business premise by immigrants that is strategic and impactful to the success and survival of the business at a fair price is hard to find. In a study done in Cape Town by Asoba and Tengeh (2016), 67.2\% of craft shop owners pointed to the fact that acquisition of a business location was practically impossible. This has pushed some immigrant small business to operate along the roadside while some have opted to operate from homes. Competition is another challenge because the majority of the immigrant small businesses are still at infancy or teenage stages, they cannot enjoy retained earnings compared to large firms, leading to their inability to stand fierce competition (Fatoki 2010; Goldstuck 2015). While building and managing personal relationships with particular individuals and firms surrounding their business is important (Coulthard \& Loos 2007), SMEs employ networking tactics to exploit opportunities. However, insufficient relationship and networking specifically with financial institutions is a great setback faced by African immigrant small businesses in Mthatha. The government has further complicated matters by putting in place stringent regulations on African immigrant business owners (Asoba \& Tengeh 2016; Ngoc, Le \& Nguyen 2009) including broad-based black empowerment labour regulations (Cross 2006) where jobs are only open to South African nationals and registration and tax requirements from the South Africa Revenue Service. South Africa is among the top 10 worst affected countries by crime and violence (Bougaardt \& Kyobe 2011; Mthimkhulu \& Aziakpono 2015). According to South African Police Service (2012), crime statistics, criminal activities and corruption meted on SMEs is a major drawback on their development and sustainability. Besides, employee theft and pilferage account for between $40 \%$ and $50 \%$ losses in most of the fast-food immigrant small businesses in South Africa (Van Scheers 2011).

With regard to running of businesses, managerial competencies are vital. For example, a business should have a manager who can lead, direct and coordinate activities for its prosperity (Abraham 2010). However, this is not the case with the majority of African immigrant businesses, which are either a one-man show or are too small to afford having a competent management employee with the aforementioned core competencies (Kim, Park \& Wier 2012). This limits management capability in most of the immigrant businesses (Rathakrishnan 2009) as well as competition of skilled and highly qualified employees with larger enterprises (Machado \& Melo 2014). Other challenges faced by African immigrant SMEs include poor access to relevant information (Urban \& Naidoo 2012), lack of skilled workforce (Liedeman et al. 2013), poor financial management skills (Smith \& Watkins 2012) and lack of knowledge of the local language, which limits effective communication, information gathering and evaluation (Habiyakare et al. 2009; Hisrich, Peters \& Shepherd 2010). The communication barrier presents key obstacles for African immigrants' business continuity prospects. Notwithstanding, the aforesaid challenges have seen the government(s) called upon to provide support in various forms (Tengeh 2013) for the prosperity of immigrant SMEs.

Having presented this status of discourses in literature revolving around challenges faced by African immigrant entrepreneurs, the implication on their businesses and to the economy and considering that Eastern Cape of South Africa where O.R. Tambo District Municipality belongs to is characterised by high rural population, high proportion of youth confronted with high levels of unemployment and great need for sustainable socio-economic development, the need for such a study was exigent. The article also elucidates 
strategic ideas to enable the municipality to formulate integrated approaches that could bring about not only sustained co-existence between immigrant entrepreneurs and communities but also socio-economic development of the region on top.

\section{Research methodology}

Zikmund and Babin (2007) refer to a research design as a master plan of methods and procedures implemented to collect and analyse data. For this study, a quantitative survey design was employed. It enabled data to be collected from a sample of African immigrant business owners in Mthatha, O.R. Tambo District Municipality, in the Eastern Cape Province of South Africa. This ensured variety (Saunders, Lewis \& Thornhill 2012) in the sample of immigrants drawn from different countries, namely Cameroon, Democratic Republic of Congo, Ethiopia, Ghana, Nigeria, Somalia and others. Sample elements were selected through simple random sampling procedure from a list of African immigrant small businesses obtained from respondent ethnic groups in Mthatha Municipality and Business Support Centre. The sample comprised 75 foreign participants who own SMEs in the municipality. A pilot study was initially conducted prior to actual data collection while external validity was ensured via the representative sample at 5\% marginal error. Data were collected through personally administered self-filling structured questionnaires, which were delivered and collected from the participants at an agreed date and time. In some cases, there were email invites where the questionnaires were emailed to participants. The data were collected throughout the entire month of October 2015, during which participants were constantly reminded to complete the questionnaire. Personal contact resulted to increased response rate. Descriptive statistics approaches utilising SPSS Version 22 statistical software package and Microsoft Excel were used to analyse the data. The major limitation of this study was the sample size because the definite population size was unknown. If all factors were constant, the researcher would have surveyed a larger sample. Unavailability of reliable statistics on the existing SMEs owned by African immigrants in Mthatha could not allow establishing the precise population. Also, the use of a smaller sample randomly selected as a result of resource constraints could not allow reaching every locality, thereby lowering the validity and reliability of the study. But this was the most suitable technique in the circumstance because it enhanced the quality of the data collected.

\section{Research results}

This section distils the major findings of the study, namely the participants' background characteristics, forms of entrepreneurship, challenges and their consequences to entrepreneurship.

\section{Background profile of participants}

The participants' background attributes are captured in Table 2 , which shows that $76 \%$ of them were men, $54.7 \%$ were
TABLE 2: Participants' background attributes.

\begin{tabular}{|c|c|c|c|}
\hline $\begin{array}{l}\text { Background } \\
\text { attribute }\end{array}$ & Value label & Number $(f)$ & Valid per cent \\
\hline \multirow[t]{2}{*}{ Gender } & Male & 57 & 76.0 \\
\hline & Female & 18 & 24.0 \\
\hline \multirow[t]{4}{*}{ Age } & $21-30$ years & 17 & - \\
\hline & $31-40$ years & 41 & - \\
\hline & $41-50$ years & 16 & - \\
\hline & $51-60$ years & 1 & - \\
\hline \multirow[t]{7}{*}{ Country of origin } & Nigeria & 29 & 38.7 \\
\hline & Cameroon & 26 & 34.7 \\
\hline & Ethiopia & 2 & 2.7 \\
\hline & Ghana & 5 & 6.7 \\
\hline & Somali & 2 & 2.7 \\
\hline & $\begin{array}{l}\text { Democratic Republic of } \\
\text { Congo }\end{array}$ & 7 & 9.3 \\
\hline & Other & 4 & 5.3 \\
\hline \multirow{4}{*}{$\begin{array}{l}\text { Duration of stay in } \\
\text { South Africa }\end{array}$} & $<5$ years & 27 & 36.0 \\
\hline & $5-10$ years & 28 & 37.3 \\
\hline & $11-15$ years & 15 & 20.0 \\
\hline & $>15$ years & 5 & 6.7 \\
\hline \multirow{4}{*}{$\begin{array}{l}\text { Years of business } \\
\text { operation }\end{array}$} & $<5$ years & 41 & 54.7 \\
\hline & $5-10$ years & 26 & 34.7 \\
\hline & $11-15$ years & 4 & 5.3 \\
\hline & $16-20$ years & 4 & 5.3 \\
\hline
\end{tabular}

Source: Survey results 2015

between 31 and 40 years and 38.7\% were from Nigeria. The majority (37.3\%) had lived in South Africa between 5 and 10 years. The majority (54.7\%) had operated their businesses in less than 5 years. This sample is typical of the start-ups owned by young immigrant entrepreneurs wishing to gain economic mileage and survival (Habiyakare et al. 2009). It is also interesting to note that there were many younger male immigrants operating businesses in the municipality than female immigrants (Rogerson 1997). Khosa and Kalitanyi (2014) affirm that the majority of African immigrant entrepreneurs are ordinarily middle-aged men.

\section{Source of capital and type of entrepreneurship}

Figure 1 shows that most participants were earning a living through various forms of businesses. More particularly, $22.8 \%$ of participants owned salons, $19 \%$ were in clothing business followed by $10.1 \%$ information and communication technologies and $8.9 \%$ second-hand goods.

It was of interest for researchers to know where migrant entrepreneurs sourced capital. The majority of the participants $(90 \%)$ started their businesses using their own resources while $8 \%$ got funding from other sources. Only a meagre 2\% received funding from banks. Researchers such as Rogerson (1997) and Khosa and Kalitanyi (2015:137) have shown that other sources key to immigrant business startup capital include family in their home countries, savings from previous work in the home country or South Africa and from friends. A study by Habiyakare et al. (2009) reported that up to $74 \%$ of participants have saved their own capital or obtained it from their relatives to start their businesses. 


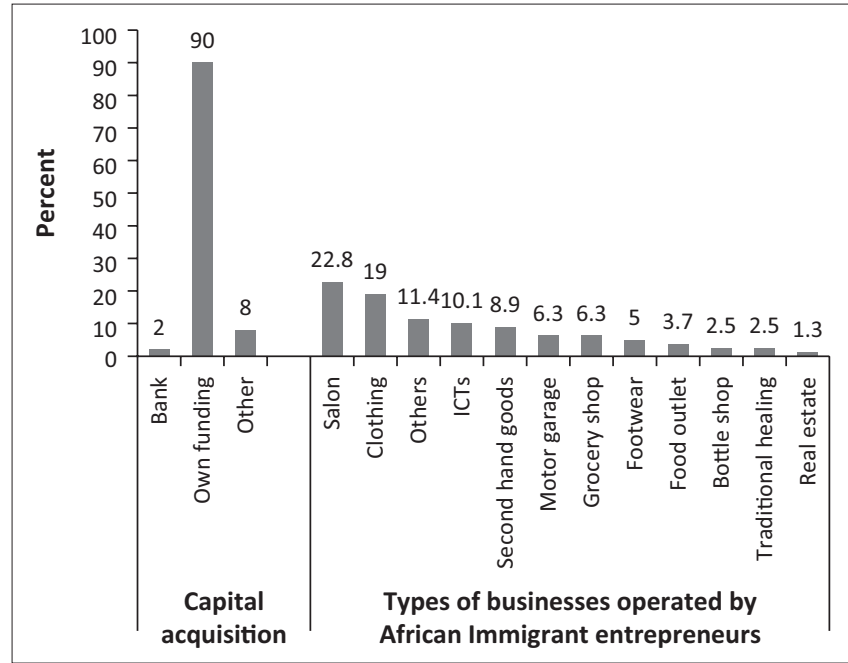

FIGURE 1: Source of capital and type of entrepreneurship.

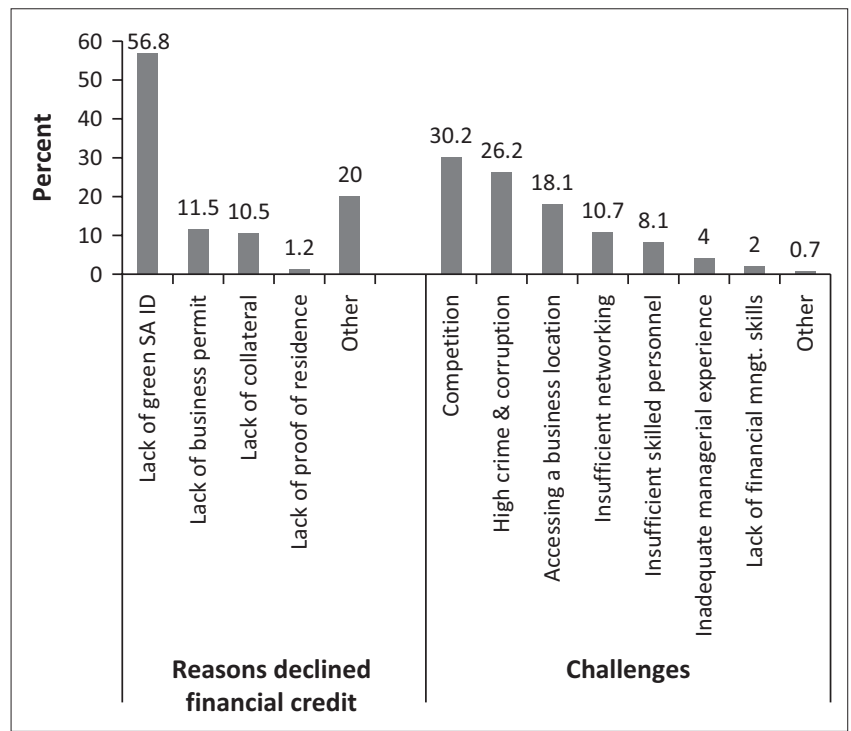

FIGURE 2: Challenges faced by African migrant entrepreneurs.

\section{Challenges facing African migrants in the conduct of their entrepreneurship}

We further requested participants to indicate the challenges they experienced while running their businesses. Migrant entrepreneurs starting a business in O.R. Tambo Municipality experienced numerous problems as explained by study participants. While lack of financing or access to credit from formal financial institutions particularly banks was more problematic (Asoba \& Tengeh 2016; Goldstuck 2015; Zolin \& Schlosser 2011), Figure 2 shows that the aforementioned problem was aggravated by migrants' lack of a green South African identity card as alluded to by most participants (56.8\%), lack of business permit (11.5\%), lack of collateral $(10.5 \%)$ and lack of proof of residence (1.2\%). A study by Asoba and Tengeh (2016) showed that short-stay permits issued to immigrant entrepreneurs are a deterrent to entrepreneurship. On the other hand, Timmons and Spinelli (2009) recognised that surety is a setback towards accessing credit by immigrant-owned businesses. Participants further mentioned the following factors as main barriers to

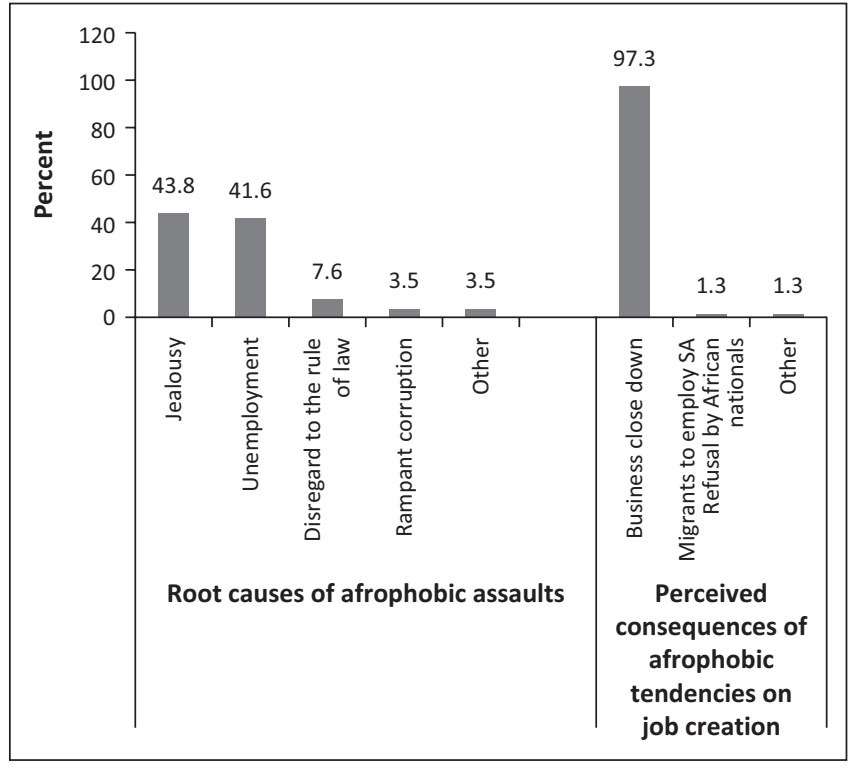

FIGURE 3: Causes and consequences of afrophobic tendencies on job creation.

entrepreneurship: competition (30.2\%), high degree of crime and corruption (26.2\%), getting a business location (18.1\%), insufficient networking (10.7\%), inadequate skilled personnel $(8.1 \%)$, inadequate managerial experience $(4 \%)$ and lack of financial management skills (2\%). Goldstuck (2015) and Mthimkhulu and Aziakpono (2015) surveyed the SMEs and showed that finance, competition, corruption and crime are the greatest threats to SMEs.

The lack of knowledge of the local language still remains a significant inhibition to smooth trading (Habiyakare et al. 2009; Hisrich et al. 2010; Khosa \& Kalitanyi 2015) even with the majority $(84.3 \%)$ of the migrant entrepreneurs, indicating using English in their communication with a few (15.7\%) being able to speak IsiXhosa. The aforementioned researchers have further suggested that sufficient networking can create space for immigrant entrepreneurs to share their problems. Similarly, Aaltonen and Akola (2014) are of the view that networking among immigrant entrepreneurs and host entrepreneurs help the former gain new skills. To circumvent the problems associated with the language barrier, which hinders effective communication and smooth running of their businesses, the study established that African immigrant entrepreneurs have developed strategies including employing locals (South Africans) in their businesses (97.4\%) while 1.3\% of entrepreneurs use hired interpreters.

\section{Perceived causes of afrophobic attacks and their consequences on entrepreneurship}

Another key challenge that adversely impacted on immigrant entrepreneurship was afrophobia (Khosa \& Kalitanyi 2014; 2015; Mutambanengwe 2013 as cited by Khosa \& Kalitanyi 2015:135). Figure 3 shows that most participants in Mthatha attributed this to jealousy (43.8\%), unemployment (41.6\%), disregard to the rule of law $(7.6 \%)$ and rampant corruption (3.5\%), among other revolving factors. A study by De Jager (2013) demonstrated that jealousy as a result of the success of foreign businesses contributed immensely to afrophobic 
attacks. We further requested participants to indicate what they thought could be the implications of such afrophobic tendencies towards African immigrant SME businesses. As indicated in Figure 3, the majority (97.3\%) of the participants stated that they would definitely close their businesses while $1.3 \%$ mentioned that they would resort to not giving jobs to South Africans. It has been argued in studies by some researchers (IOM 2006; Radipere 2012) that South African nationals should view immigrant entrepreneurs as contributors to the economy via job supply. In addition, Khosa and Kalitanyi (2015) affirm that initiatives by a country that support immigrant entrepreneurship lead to economic triumph and work creation.

\section{Analysis, discussion and implications}

The aim of this study was to identify and document challenges impeding entrepreneurship among African immigrant SME owners with a view to justifying the need for appropriate interventions that would strengthen the local business environment, particularly in O.R. Tambo District Municipality for the realisation of the national socio-economic targets. Our analysis of the challenges faced by African immigrant entrepreneurs produced the following results: that lack of access to financing puts a restraint on African immigrants' SMEs growth and sustainability (Urban \& Naidoo 2012) and that the nature and magnitude of afrophobic tendencies and attacks on African immigrant businesses has adverse negative effects on their continuity and survival. Consequently, this is harmful to job creation and socio-economic well-being of a community. Other challenges included lack of access to business location or premise amid high rental costs, corruption, increased crime levels, stiff competition and inadequate human resources and skills.

The municipal authorities may initiate programmes that could help allocate business premises or areas where immigrants may operate from. This will be advantageous in that, apart from acting as means of cooperation and integration with locals, it would be an income generation project for the municipality through rental income and provide a form of security assurance to the immigrant entrepreneurs. The aforementioned components should be encouraged because they are central to the social interdependence and interrelationship for the realisation of goals of both parties. On the other hand, African immigrant entrepreneurs should strive and form connections with local contacts (Khosa \& Kalitanyi 2014) because this becomes a bridge towards working in harmony.

There is no doubt that the success of local or municipality socio-economic efforts will feed into and contribute to the excellence of the provincial and national targets, by reducing poverty levels and reversing unemployment trends. Social integration among African immigrant entrepreneurs and local communities is paramount. In view of this, continuous sensitisation of the general public through a multimedia approach is a critical intervention all levels of government should invest in to bring about the understanding that foreign entrepreneurship, particularly from African immigrants, provides work and consequently income not only to the immigrants but also to South African communities (Bogan \& Darity 2008).

As such, the government(s) could prioritise social integration as critical for programmatic interventions. Strengthening responsible institutions through legislation and involving stakeholders are key options that the government should consider towards entrepreneurship among 'all' which will have a social and economic impact in the future, and by extension, economic prosperity of the region. To sum up, considering such suggestions will help the relevant systems of government improve their social policies with respect to entrepreneurial migrants, which in turn could lead to a cohesive environment that is conducive to doing business.

Considering that the research sample was relatively small as a result of the time-limited nature of the study, it was not representative of the whole population. Perhaps the findings may be treated as pilot insights into the defined target population. Therefore, future research should consider all small, micro and medium business enterprises to maximise data saturation and scope. Previously, concern has been raised on what immigrant entrepreneurs do to succeed in their businesses as compared to their host populations (Liedeman et al. 2013). Future enquiry should also evaluate the interrelationships among African immigrant entrepreneurial characteristics and business performance with 'some' biographic profile acting as mediating variables. A comparative study on the performance of African immigrant businesses and those of host populations is another rich area. In addition, the study may consider a more robust research methodology that can lead to the production of precise and consistent findings.

\section{Conclusion}

Currently, typical of many local municipalities' economies including O.R. Tambo are immigrant SMEs, symbolising the dynamic changes in their socio-economic landscapes. Irrespective of their operational environments, there is commercial hopefulness among the majority of African immigrant entrepreneurs. Conversely, negative sentiments were expressed by over $97.3 \%$ of the participants who reckoned that afrophobia is increasingly becoming a major setback to their existence and livelihood. This investigation into a sample of migrants in Mthatha area not only provided comparable results as other wide-ranging regional and overseas findings but also showed the gravity of the challenges above all afrophobic. These are complex issues requiring more systemic solutions than merely overlooking the whole problem. Therefore, our proposals for management practice are threefold:

- Refocus on adequate 'liberal' and effective public policy interventions that would advance progression as well as encourage inclusive attitude and integration, of which could help bring long-lasting understanding and co-existence between native population and immigrant business owners. 
- Policy makers need to recognise the existing and unforeseen contribution from immigrant SMEs because they could act as a catalyst for future employment creation and trigger local economic development and planning for O.R. Tambo District Municipality.

- It is critical and urgent that all stakeholders in particular the relevant arms of government concerned both at national and municipal levels must censure afrophobic speeches and actions, deplore attacks and confront collective violence against migrant-owned businesses because they are unlawful and racist and a threat to national security, critical to the growth of an economy. In addition, there is need to appropriately use the existing legal structures to act against those found guilty to have participated implicitly or explicitly in the persecution of migrants. This will act as a deterrent to any nature of afrophobic violence directed towards migrants and their ventures.

\section{Acknowledgements Competing interests}

The authors declare that they have no financial or personal relationships which may have inappropriately influenced them in writing this article.

\section{Authors' contributions}

B.L.N. conducted the study as part of his postgraduate degree in Business Management at Walter Sisulu University. Data collected towards fulfilling this degree were used in the preparation of this article. S.R. supervised the research conducted by B.L.N. E.E.M. used the data from this research to develop the content of this article. E.E.M. performed all the data analysis. S.R. proofread the article.

\section{References}

Aaltonen, S. \& Akola, E., 2014, Lack of trust - The main obstacle for immigran entrepreneurship? viewed 05 June 2015, from http://www.pyk2.aalto.fi/ncsb 2012/aaltonen.pdf

Abraham, D., 2010, 'Local economic development in South Africa: A useful tool for sustainable development', Urban Forum 14(2), 185-200.

Asoba, S.N. \& Tengeh, R.K., 2016, 'Analysis of start-up challenges of African immigrantowned businesses in selected craft markets in Cape Town', Environmental Economics 7(2), 97-105. https://doi.org/10.21511/ee.07(2).2016.10

Bear, M., Bradnum, P., Tladi, S. \& Pedro, D., 2005, Making retail markets work for the poor - Why and how Triple Trust Organisation decided to intervene in the spaza market in South Africa, The Seep Network, Washington, DC.

Benedict, E.A. \& Venter, P.F., 2010, 'Education, entrepreneurial mindset and innovation: Necessary ingredients for increasing entrepreneurial activity in South Africa', International Journal of Entrepreneurship and Innovation management 11(2), 239-253. https://doi.org/10.1504/IJEIM.2010.030071

Bogan, V. \& Darity, W., 2008, 'Culture and entrepreneurship? African American and I Qmmigrant self-employment in the United States', Journal of Social Economics 37(1), 1999-2019. https://doi.org/10.1016/j.socec.2007.10.010

Bougaardt, G. \& Kyobe, M., 2011, 'Investigating the factors inhibiting SMEs from recognising and measuring losses from cybercrime in South Africa', Electronic Journal of Information Systems Evaluation 14(2), 167-178.

Canetti-Nisim, D. \& Pedahzur, A., 2003, 'Contributory factors to political xenophobia in a multi-cultural society: The case of Israel', International Journal of Intercultura Relations 27(9), 307-333. https://doi.org/10.1016/S0147-1767(03)00014-2

Cant, M., 2012, 'Challenges faced by SMEs in South Africa: Are marketing skills needed?', International Business and Economics Research Journal 11(10), 1107-1116. https://doi.org/10.19030/iber.v11i10.7256

Chodokufa, K., 2009, An analysis of the business relationship between SMEs and insurance companies in Nelson Mandela Metropolitan area, MCom, University of Fort Hare.
Clive, N., 2015, 'Foreigners must go home', The Citizen, 23 March, viewed 05 June 2015, from http/www.citizen.co.za/349347/foreigners-must-go-home-king-zwelithini/

Coulthard, M. \& Loos, J., 2007, Networking, the link in firm based entrepreneurial operation (EO) performance model, viewed 18 September 2015, from http:// www.buseco.monash.edu.au/mgt/staff/coulthard.max.html

Cronje, F., 2009, 'Xenophobia: Nine causes of the current crises', Politics Web, 20 May, viewed 05 June 2015, from http://www.politicsweb.co.za/politicsweb/view/ politcsweb/en/page 71619 ?oid=89859\&sn=Detail

Cross, C., 2006, 'Foreign migration's impact: the skills gap?', Human Sciences Research Council (HSRC) Review 4(3), 1-17.

Crush, J., 2000, 'The dark side of democracy: Migration, xenophobia and human rights in South Africa', International Migration 38(6), 103-133. https://doi.org/ 10.1111/1468-2435.00145

Crush, J. \& Ramachandran, S., 2009, Xenophobia, international migration and human development: Human Development Research Paper 47, United Nations
Development Programme, viewed 05 June 2015, from http://ideas.repec.org/p/ hdr/papers/hdrp-2009-47.html

Crush, J., Ramachandran, S. \& Pendleton, W., 2013, Soft targets: Xenophobia, public violence and changing attitudes to migrants in South Africa after May 2008, South violence and changing attitudes to migrants in South Africa after May 2008, South
African Migration Programme - Migration Policy series No 64, South African African Migration Programme - Migration Policy series
Migration Programme (SAMP), Megadigital, Cape Town.

Dalhammar, T., 2004, 'Voices of entrepreneurship and small business-immigrant enterprises in Kista', Licentiate of Philosophy Degree, Royal Institute of Technology, enterprises in Kista, Licentiate of Philosophy Degree, Royal Institute of Technology,
viewed 24 April 2015, from http://www.divaportal.org/smash/get/diva2:7559/ fulltext01.pdf

Dana, L.P., 2007, Handbook of research on ethnic minority entrepreneurship; a coevolutionary view on resource management, Edward Elgar Publishing, Cheltenham.

De Jager, S., 2013, 'Xenophobia "has roots in jealousy"', The Herald, 06 May, viewed 16 June 2015, from http://www.peherald.com/news/article/14555.

Fairlie, R.W., 2012, 'Immigrant entrepreneurs and small business owners and their access to financial capital', Economic Consulting Santa Cruz 9(1), 1-46.

Fatoki, O., 2010, 'Obstacles to growth of new SMEs in South Africa: A principal component analysis approach', African Journal of Business Management 4(5), 729-738.

Fatoki, O., 2013a, 'An investigation into the financial bootstrapping methods used by migrant entrepreneurs in South Africa', Journal of Economics 4(2), 89-96. https:// doi.org/10.1080/09765239.2013.11884968

Fatoki, O., 2013b, 'The determinants of immigrant entrepreneurs' growth expectations in South Africa', Journal of Social Sciences 37(3), 209-216. https://doi.org/10.1080/ 09718923.2013.11893219

Fatoki, O., 2014, 'Immigrant entrepreneurship in South Africa: Current literature and research opportunities', Journal of Social Sciences 40(1), 1-7. https://doi.org/10.1080/ research opportunities', Jour
09718923.2014 .11893297

Fatoki, O. \& Patswawairi, T., 2012, 'The motivations and obstacles to immigrant entrepreneurship in South Africa', Journal of Social Sciences 32(2), 133-142. https://doi.org/10.1080/09718923.2012.11893059

Gastrow, V. \& Amit, R., 2012, Elusive justice: Somali traders access to formal and informal justice mechanisms in the Western Cape, Research Report ACMS, Wits, Johannesburg, viewed 10 August 2016, from www.migration.org.za/uploads/ docs/report-38.pdf

Goldstuck, A., 2015, SME survey 2015, World Wide Worx: SME Survey (Pty) Ltd. viewed 10 August 2016, from http://www.smesurvey.co.za/research.htm

Habiyakare, E., Owusu, R.A., Mbare, O. \& Landy, F., 2009, 'Characterising African immigrant entrepreneurship in Finland', in S.P. Sigué (ed.), Repositioning African business and development for the 21st century. Peer-reviewed Proceedings of the 10th Annual International Conference held at the Speke Resort \& Conference Centre, Makerere University Business School, Kampala, Uganda, May 19-23, viewed 10 August 2016, from http://www.iaabd.org/?q=past-conference

Hiebert, D., 2002, 'Economic association of immigrant self-employment in Canada', International Journal of Entrepreneurial Behaviour and Research 8(2), 93-112. https://doi.org/10.1108/13552550210423741

Hisrich, R.D., Peters, M.P. \& Shepherd, A., 2010, Entrepreneurship, 8th edn., McGrawHill, New York.

Hohn, M.D., 2012, Immigrant entrepreneurs creating jobs and strengthening the economy, Immigrant Learning Centre, Washington, DC.

Human Rights Commission, 1999, Report on the arrest and detention of persons in terms of the aliens control Act, Wordsmiths Publishing Services, Johannesburg.

Hunter, N. \& Skinner, C., 2003, 'Foreign street traders working in inner city Durban: Local government policy challenges', Urban Forum 14(4), 309-319. https://doi. org/10.1007/s12132-003-0016-7

International Organization for Migration (IOM), 2006, Integration in today's mobile world, IOM, Geneva, viewed 17 May 2015, from http://publications.iom.int/ bookstore/WMR_2006_English.

Kahn, S., La Mattina, G., MacGarvie, M. \& Ginther, D.K., 2013, 'Hobos', 'star' and immigrant entrepreneurs, viewed 15 May 2015, from http://people.bu.edu/ skahn/entrepreneurship_kahn\%20et $\% 20$ al.pdf

Kalitanyi, V. \& Visser, K., 2010, 'African immigrants in South Africa: Job takers or job creators?', South African Journal of Economic and Management Sciences 13(4), 376-390. https://doi.org/10.4102/sajems.v13i4.91

Khosa, R.M., 2014, 'An analysis of challenges in running micro-enterprises: A case of African foreign entrepreneurs in Cape Town, Western Cape', MTech Business Administration in Entrepreneurship, Cape Peninsula University of Technology. 
Khosa, R.M. \& Kalitanyi, V., 2014, 'Challenges in operating micro-enterprises by African foreign entrepreneurs in Cape Town, South Africa', Mediterranean Journal of Social Sciences 5(10), 205-215. https://doi.org/10.5901/mjss.2014.v5n10p205

Khosa, R.M. \& Kalitanyi, V., 2015, 'Migration reasons, traits and entrepreneurial motivation of African immigrant entrepreneurs', Journal of Enterprising Communities: People and Places in the Global Economy 9(2), 132-155. https:// doi.org/10.1108/JEC-07-2014-0011

Kim, Y., Park, M. \& Wier, B., 2012, 'Is earnings quality associated with corporate social responsibility?', The Accounting Review 87(3), 761-796. https://doi.org/10.2308/ accr-10209

Kongolo, M., 2010, 'Job creation versus job shedding and the role of SMEs in economic development', Journal of Business 4(11), 2288-2295.

Landau, L.B., Ramjathan-Keogh, K. \& Singh, G., 2005, Xenophobia in South Africa and problems related to it, University of the Witwatersrand, Johannesburg.

Lemes, P.C., Almeida, D.J.G. \& Hormiga, E., 2010, 'The role of knowledge in the immigrant entrepreneurial process', International Journal of Business Administration 1(1), 68-79.

Liedeman, R., Charman, A., Piper, L. \& Petersen, L., 2013, Why are foreign run spaza shops more successful? The rapidly changing spaza sector in South Africa, viewed 24 July 2015, from http://www.econ3×3.org/sites/default/files/articles/ Liedeman $\% 202013 \% 20$ spaza $\% 20$ shops $\% 20$ FINAL_0.pdf

Mac, A.N. \& Bhaird, C., 2010, Resourcing small and medium sized enterprises: A financial growth life cycle, SPI Publisher Service, New York.

Machado, C. \& Melo, P., 2014, Effective human resources management in small and medium enterprises: Global perspectives, (pp. 1-526). Hershey, PA: IGI Global. Doi:10.4018/978-1-4666-4731-2.

Maharaj, B., 2004, Immigration to post -apartheid South Africa: Global Migration Perspectives, No. 1, Global Commission on International Migration, Geneva, viewed 26 July 2016, from www.iom.int/.../shared/mainsite/policy_and_research/ gcim/gmp/gmp1.pdf

Mason, C. \& Rown, R., 2013, 'Creating good public policy to support high growth firm', Smal Business Economics 40(2), 211-225. https://doi.org/10.1007/s11187-011-9369-9

Matsinhe, D.M., 2011, 'Africa's fear of itself: The ideology of Makwerekwere in South Africa', Third World Quarterly 32(2), 295-313. https://doi.org/10.1080/014 36597.2011.560470

McKinley, B., 2006, Facts and figures: Migration in the 21st century, viewed 07 June 2015, from http://www.iom.int/

Mohsam, F. \& Van Brakel, P.A., 2011, 'Information and knowledge sharing trends of small and medium-sized enterprises in the Western Cape, South Africa', South African Journal of Information Management 13(1), 1-10. https://doi.org/10.4102/ sajim.v13i1.462

Mthimkhulu, A.M. \& Aziakpono, M.J., 2015, 'What impedes micro, small and medium firms' growth the most in South Africa? Evidence from World Bank enterprise surveys', South African Journal of Business Management 46(2), 15-27. https://doi. org/10.4102/sajbm.v46i2.88

Mudi-Okorodudu, C., 2011, 'Immigrant street traders in South Africa: The economics, the struggle and the tensions', Paper presented at the annual Research Committee 21 (RC21) Conference, Amsterdam, Netherlands, 7-9th July.

Nestorowicz, J., 2011, Known knowns and known unknowns of the immigrant selfemployment: Selected issues: CMR Working Papers 45/103, Centre of Migration Research, University of Warsaw, Warsaw, Poland.

Ngoc, T.B., Le, T. \& Nguyen, T.B.M., 2009, 'The impact of networking and bank financing: The case of small and medium enterprises in Vietnam', Entrepreneur financing: The case of small and medium enterprises in Vietnam', Entrepreneur
Theories and Practice 33(4), 867-887. https://doi.org/10.1111/j.1540-6520. Theories and
2009.00330.x

Ntsika Enterprise Promotion Agency, 2012, State of small business development in South Africa 1995, Ntsika Enterprise Promotion Agency, viewed 27 April 2015, from http://www.polity.org.za/govdoc/whitepaper/smallbiz.html?rebookmark=1

Organisation for Economic Co-operation and Development (OECD), 2013, Economic surveys South Africa report-March 2013, OECD, viewed 18 July 2016, from www. oecd.org/eco/surveys/South\%20Africa\%202013\%200verview\%20FINAL.pdf

Radipere, N.S., 2012, An analysis of local and immigrant entrepreneurship in the South African small enterprise sector (Gauteng Province), DCom., University of South Africa.

Radipere, N.S. \& Dhiwayo, S., 2013, 'An analysis of local and immigrant entrepreneurs in South Africa', International Journal of Advanced Research in Business 1(2), 34-39.
Rathakrishnan, L., 2009, Small and medium enterprises under globalisation: Challenges and opportunities, Kalpasz Publications, Delhi.

Rogerson, C.M., 1997, International migration, immigrant entrepreneurs and South Africa's small enterprise economy. The Southern African Migration Project: Migration policy series No. 3, The Institute for Democracy in South Africa, Cape Town, South Africa.

Saunders, M., Lewis, P. \& Thornhill, A., 2012, Research methods for business students, 6th edn., Pearson, Harlow.

Schuler, S.R., Islam, F. \& Rottach, E., 2011, 'Women's empowerment revisited: A case study from Bangladesh', Journal of Small Business Management 28, 30-38.

Shary, F., 2000, 'Immigrants' contribution to America', Business Week, New York, $3(3675), 16$.

Smith, Y. \& Watkins, J., 2012, 'A literature review of SME risk management practices in South Africa', African Journal of Business Management 6(21), 6324-6330.

South African Police Service, 2012, Crime statistics release of the 2012/13, South Africa Police Service National Crime Statistics, viewed 15 June 2015, from http:// wwwdefenceweb.co.za

Statistics South Africa (Stats SA), 2009, 'Labour force survey (LFS)', May 2009, P0210, Pretoria, South Africa, viewed 24 April 2015, from www.statssa.gov.za

Statistics South Africa (Stats SA), 2010, 'Labour force survey (LFS)', September 2010, P0210, Pretoria, South Africa, viewed 24 April 2015, from www.statssa.gov.za

Statistics South Africa, 2014, Quarterly labour force survey: Statistical release P0211 quarter 2, Statistics South Africa, viewed 05 June 2015, from http://www.statssa.gov.za

Tambunan, T., 2009, Development of small and medium enterprises in ASEAN countries, Readworthy Publication (P) Ltd, New Delhi.

Tengeh, R.K., 2013, 'Advancing the case for the support and promotion of African immigrant-owned businesses in South Africa', Mediterranean Journal of Social Sciences 4(2), 347-359. https://doi.org/10.5901/mjss.2013.v4n2p347

Tengeh, R.K., Ballard, H. \& Slabbert, A., 2012, 'Do immigrant owned businesses grow financially? An empirical study of African immigrant-owned businesses in the Cape Town metropolitan area in South Africa', African Journal of Business Management 6(19), 6070-6081.

Tengeh, R.K. \& Lapah, C.Y., 2013, 'The migratory trajectories of the post 1994 generation of African immigrants in South Africa: An empirical study of the street vendors in the Cape Town metropolitan area', Medical Journal of Social Science 4(4), 2039-2117.

Thulani, G., 2015, 'Police minister: KZN attacks are not just xenophobic', Mail \& Guardian, 14 April, viewed 06 June 2015, from http://www.Mail\&Guardian.co.za/tol/news

Timeslive, 2015, 'Minister Lindiwe Zulu: Small business development department budget vote 2015/2016', Times Live, 20 May, viewed 06 June 2015, from http:// timeslive.co.za

Timmons, J.A. \& Spinelli, S. Jr., 2009, New venture creation: Entrepreneurship for the 21st Century, 8th edn., McGraw-Hill, New York.

United Nations, 2006, International migration report 2006: A global assessment, Global Publishers, New York.

Urban, B. \& Naidoo, R., 2012, 'Business sustainability: Empirical evidence on operational skills in SMEs in South Africa', Journal of Small Business and Enterprise Development 19(1), 146-163. https://doi.org/10.1108/14626001211196451

Van Scheers, L., 2011, 'Small medium enterprises marketing skills challenges in South Africa', African Journal of Business Management 5(13), 5048-5056.

Veerabhadrappa, H., 2009, Management and entrepreneurship, New Age International, New Delhi.

Vinogradov, E., 2008, Immigrant entrepreneurship in Norway, viewed 25 February 2015, from http://brage.bibsys.no/xmlui/handle/11250/140348

Washinyira, T., 2015, How immigrants contribute to the SA economy. Groundup news article, 17 June, viewed 14 July 2016, from http://www.groundup.org.za/article/ how-immigrants-contribute-sa-economy_3043/

Zikmund, W.G. \& Babin, B.J., 2007, Essentials of marketing research, Thomson, SouthWestern Australia, Mason.

Zolin, R. \& Schlosser, F., 2011, 'The role of immigrant entrepreneurs in international new ventures', in A. Maritz (ed.), Proceedings of the 8th AGSE International Entrepreneurship Research Exchange, pp. 1187-1198, Swinburne University of Technology, Melbourne, VC, viewed 10 August 2016, from eprints.qut.edu. au/41695/1/AGSE_-_Zolin_noPW.pdf 